\author{
Oliwia McFarlane \\ Collegium Medicum Uniwersytet Mikołaja Kopernika w Toruniu \\ Kornelia Kędziora-Kornatowska \\ Collegium Medicum Uniwersytet Mikołaja Kopernika w Toruniu
}

\title{
Przyjmowanie leków w późnej dorosłości - potrzeba edukacji zdrowotnej
}

Medication use in the elderly - the need for health education

Streszczenie. Ogólnoświatowy trend wskazujący na rosnącą oczekiwaną długość życia i wzrost w demograficznej strukturze wielu społeczeństw odsetka osób w wieku emerytalnym powoduje, iż edukacja zdrowotna seniorów stanowi obecnie niezwykle ważne zagadnienie. Niewystarczające przygotowanie do zapobiegania i radzenia sobie z licznie występującymi w zaawansowanym wieku zagrożeniami sygnalizują konieczność zwiększenia potencjału wiedzy i umiejętności tej grupy osób w zakresie zdrowia. Artykuł ma na celu podjęcie zagadnienia farmakoterapii wieku podeszłego, które może wiązać się ze - stosunkowo rzadko opracowywanym - nadużywaniem i uzależnieniem od leków u osób starszych oraz wynikającymi z nich problemami natury medycznej, psychologicznej i społecznej. Uświadomienie zarówno problemów związanych ze starością, jak i pozytywnych jej aspektów, a także przekazanie zasad farmakoterapii seniorom jest kluczowe w sytuacji braku dobrze przemyślanej polityki wobec ochrony zdrowia osób starszych.

Słowa kluczowe: starzenie się, edukacja zdrowotna, przyjmowanie leków, uzależnienie

Summary. Worldwide tendency of a rising life expectancy among populations, resulting in an increase of the retired in the demographic structure, makes the senior health education an extremely important issue. Insufficient preparation to prevent and cope with multiple health threats associated with aging indicates an urgent need to increase seniors' knowledge and skills in the area of health. The paper aims at depicting geriatric pharmacotherapy that entails medication abuse and dependency among the elderly, both resulting in serious problems of medical, psychological, and sociological nature. Educating on both negative and positive aspects of aging, as well as the pharmaceutical use are essential considering the lack of proper health care policy for the elderly.

Keywords: aging, health education, medication use, addiction 
W ostatnich latach nastąpił wyraźny wzrost zainteresowania zagadnieniami dotyczącymi seniorów, a to za sprawą systematycznie rosnącej liczby osób dożywających późnej starości. Oczekiwana długość życia, wynosząca w roku 2015 w Polsce 73,4 lat w przypadku mężczyzn oraz 81,2 lat wśród kobiet, osiągnie w roku 2050 odpowiednio 82,1 oraz 87,6 (GUS, 2014). Za granicę starości chronologicznej, wyznaczonej liczbą przeżytych lat, uważa się przekroczenie 65. (wg Organizacji Narodów Zjednoczonych - ONZ) lub 60. (wg Światowej Organizacji Zdrowia - WHO) roku życia. W latach 2015 i 2030 liczba osób starszych na świecie wzrośnie o 56\%, z obecnych 901 milionów do ponad 1,4 miliarda. Do roku 2030 osób starszych będzie więcej niż dzieci w wieku 0 -9 lat; natomiast do roku 2050 na świecie będzie więcej osób po 60. roku życia niż osób w wieku 10-24 lata. Liczba osób najstarszych również wzrasta: populacja światowa po 80. roku życia zwiększy się ze 125 milionów w 2015 do 202 milionów w 2030 i 434 milionów w 2050 (World Population Ageing Highlights, 2015). Sytuacja w Polsce stanowi niejako odzwierciedlenie trendów globalnych. Polska już w 2010 roku należała do krajów starych demograficznie, gdyż odsetek osób w wieku powyżej 65 roku życia wynosił 13,6\% (GUS, 2011). Prognozy są pod tym względem niekorzystne. Przewiduje się bowiem, że do roku 2050 nastąpi istotna zmiana struktury demograficznej, wyrażająca się zwiększeniem udziału tej grupy w liczbie ludności Polski do ponad 30\%, co oznacza wzrost liczebności tej zbiorowości o 5,4 miliona osób (GUS, 2014).

Zmiany demograficzne już teraz są więc podstawą do weryfikacji postaw społecznych, procedur medycznych i tworzenia systemów wsparcia $\mathrm{w}$ zakresie związanych ze starzeniem się problemów wielorakiej natury. Starzenie się ma bowiem charakter dynamiczny i można je rozpatrywać na co najmniej trzech płaszczyznach: biologicznej, psychologicznej i społecznej. W sensie biologicznym jest ono postępującym i uogólnionym uszkodzeniem wszystkich funkcji organizmu, powodującym utratę adaptacyjnej odpowiedzi na stres i rosnące ryzyko chorób zależnych od wieku (Wolański, 2005). W płaszczyźnie psychologicznej starzenie się oznacza oddziaływanie upływu czasu na osobowość oraz na życie emocjonalne i duchowe człowieka. Na sferę psychiczną wpływają głównie zmiany dotyczące układu nerwowego i osłabienia procesów poznawczych. W wymiarze społecznym zachodzą przede wszystkim zmiany będące skutkiem stopniowego wycofania się z życia społeczno-zawodowego, zwłaszcza w momencie przekraczania granicy wieku emerytalnego. Postęp medycyny i wzrost jakości życia przyczyniły się do tego, że coraz częściej możemy zetknąć się ze specyfiką funkcjonowania, a także różnorodnymi problemami zdrowotnymi u osób starszych. Oso- 
by w podeszłym wieku tym bardziej powinny zdawać sobie sprawę konieczności prowadzenia aktywnego trybu życia, wdrażania prewencji schorzeń, a także dbania o dobrostan w zakresie psychicznym.

\section{Pomyślne starzenie się a edukacja zdrowotna}

Jakość życia osób starszych może być wysoka, jeśli tylko wdrożone zostaną strategie optymalizowania szans zdrowotnych oraz związanych z uczestnictwem i bezpieczeństwem poprzez aktywność. Pojęcie to nie oznacza bynajmniej jedynie fizycznej sprawności, ale czynny udział w życiu społecznym, ekonomicznym, kulturalnym czy duchowym. Pomyślne starzenie się zgodnie z koncepcją Ryff, składa się z sześciu wymiarów aktywnego funkcjonowania:

1. Cel życiowy, najlepiej oparty o społeczny wymiar starości; wraz z przejściem na emeryturę często obserwuje się jego zaburzenie i determinację pozostałych ról życiowych przez rolę emeryta, co w konsekwencji doprowadza do wykluczenia społecznego jednostki;

2. Pozytywne relacje z ludźmi oparte na zaufaniu;

3. Panowanie nad otoczeniem, oznaczające odwagę w podejmowaniu aktywności;

4. Autonomia psychiczna i fizyczna rozumiana jako zdolność i możliwość decydowania o sobie, polegająca na sprawności, samodzielności, braku konieczności korzystania z pomocy innych osób czy instytucji;

5. Rozwój osobisty, opierający się o potrzebę edukacji, jak również poczucie podążania za postępem cywilizacyjnym;

6. Samoocena kształtowana w oparciu nie o stereotyp starości, a doświadczenie życiowe generujące pozytywne uczucia oraz prestiż (Halicki 2010).

Wyjątkowo ważnym aspektem wpływającym na jakość starzenia się jest edukacja. Niski stopień wykształcenia, rozumianego jako wiedza, umiejętności i kompetencje społeczne, jest uważany za główny czynnik prowadzący do wielu niekorzystnych zjawisk, zwiększający ryzyko niepełnosprawności oraz utraty zdrowia, a nawet życia wśród osób starzejących się. Według WHO, solidna edukacja w młodości, połączona z możliwościami uczenia się w ciągu całego życia, powoduje, że ludzie w wieku podeszłym mogą lepiej adaptować się do zmieniającego się środowiska przy zachowaniu autonomii i niezależności. Jak już wspomniano, prawdopodobnie już niedługo osoby starsze będą stanowić największą grupę społeczną. W ślad za tą transforma- 
cją powinna powstać nowa polityka edukacyjna, skierowana właśnie do seniorów. Polityka oznaczająca wspieranie wiedzy, umiejętności i kompetencji tej grupy osób, pozwalając im na pełniejsze uczestniczenie w życiu społecznym i w konsekwencji - pomyślne starzenie się.

Edukacja zdrowotna jest procesem mającym na celu wypracowanie pozytywnych zachowań zdrowotnych, umożliwiających świadome dążenie do zachowania czy przywrócenia zdrowia. Uzyskane kompetencje mają pomagać w podejmowaniu właściwych wyborów dotyczących stylu życia. Należy podkreślić, iż nabywanie wiedzy, kształtowanie umiejętności i postaw sprzyjających dobrostanowi fizycznemu i psychicznemu nie stanowią - jak się powszechnie uważa - domeny wyłącznie osób młodszych, ale nabywane są $\mathrm{w}$ toku całej egzystencji. Stanowią one bowiem podstawę do tego, by w pełni uczestniczyć w życiu społecznym, odnajdując się w rolach, które zmieniają się z upływem czasu. Zespół działań inspirowanych zadaniami umożliwiającymi zachowanie zdrowia, dbanie o nie i zapobieganie jego utracie, mieści się jednocześnie w trzech wymiarach: informacyjnym, czynnościowym i motywacyjnym. Wymiar informacyjny związany jest z oświatą zdrowotną, gdzie konieczne jest dostarczanie wiedzy o zdrowiu, jego zagrożeniach i możliwościach ochrony. Obszar czynnościowy, oznaczający wychowanie zdrowotne, wymusza niejako nabywanie prozdrowotnych nawyków. Aspekt motywacyjny, którego zadaniem jest pobudzanie aktywności własnej ukierunkowanej na zdrowie, zorientowany jest $z$ kolei na wyzwolenie w jednostce zadowolenia $z$ bycia zdrowym i wewnętrznej potrzeby utrzymania tego stanu, a także zainteresowania sposobami jego podnoszenia.

Pozytywne efekty kształcenia seniorów w zakresie edukacji zdrowotnej mogą być osiągnięte dzięki przestrzeganiu następujących zasad:

- poszerzania wiedzy, rozwijania umiejętności i poszerzania kompetencji w zakresie sposobów unikania ryzyka zdrowotnego, promowania zdrowia, zmieniania zachowań i postaw zdrowotnych, wspierania innych w promowaniu zdrowia i zapobieganiu problemom zdrowotnym;

- kształtowania przekonań, że zdrowie należy rozumieć wielowymiarowo, tzn. nie tylko w aspekcie medycznym, ale także psychospołecznym, kulturowym, środowiskowym i ekonomicznym, i że warunkiem jego poprawy jest umiejętne korzystanie ze wszystkich zasobów życiowych poznawania sposobów wykorzystywania nabytych umiejętności promowania zdrowia w praktyce $\mathrm{z}$ wykorzystaniem doświadczeń lokalnych i standardów krajowych i międzynarodowych; 
- propagowania poglądu, iż zdrowie może być dostępne dla wszystkich, ze szczególnym uwzględnieniem tych osób starszych, które są w najtrudniejszej sytuacji zdrowotnej i ekonomicznej;

- korzystania z tych metod promowania zdrowia, które są poparte wynikami badań naukowych (Szymborski i wsp., 2014, s. 39).

\section{Problemy farmakoterapii osób starszych}

Wraz z wiekiem częstość występowania wielu chorób zwiększa się, co sprawia, że wielochorobowość i związana z nią wielolekowość należą do typowych cech wieku podeszłego. Wszelkie zmiany patologiczne nakładają się na zmiany starcze, co może powodować, że są trudniejsze do zdiagnozowania, szybciej prowadzą do zachwiania homeostazy i wydłużają okres zdrowienia. W leczeniu farmakologicznym pacjentów w podeszłym wieku należy uwzględnić zmiany farmakokinetyki i farmakodynamiki wynikające z naturalnego procesu starzenia się organizmu, a także kontekst społeczno-ekonomiczny, który nierzadko jest odmienny od młodszych grup wiekowych. Mniejszy dochód, a większe wydatki na leczenie, utrata partnera, samotność, poczucie nieprzydatności i samo znaczenie choroby, która dla seniora może zwiastować utratę samodzielności, a dla młodszych grup wiekowych oznacza zwykle co najwyżej przerwę w pracy czy zmniejszenie dochodu, wpływa wielokierunkowo na proces leczenia (Ksiądzyna, Szeląg, 2013, s. 116).

Chorzy geriatryczni stanowią olbrzymią grupę pacjentów zgłaszających się po porady medyczne i zażywających leki wydawane na podstawie recepty oraz preparaty dostępne bez recepty (over the counter, OTC). Około $65 \%$ osób po 65. roku życia zmaga się z dwoma lub więcej chorobami przewlekłymi (Wolff i wsp., 2002); inne badania wskazują, że niemal $40 \%$ cierpi z powodu czterech lub większej liczby chorób przewlekłych (Lochner, Cox, 2013). Starsi chorzy przyjmują średnio od 3 do 8 leków, przy czym osoby samodzielne przede wszystkim leki przeciwbólowe, moczopędne, kardiologiczne i uspokajające, podczas gdy pensjonariusze domów opieki - którzy zwykle stosują więcej preparatów - głównie leki przeciwpsychotyczne, uspokajające, nasenne, moczopędne, kardiologiczne, przeciwbólowe i antybiotyki. Polifarmakoterapia wiąże się z wysokimi kosztami nie tylko w wymiarze indywidualnym, ale i społecznym (Ksiądzyna, Szeląg, 2013, s.116). Dla przykładu, 11\% populacji Kanady powyżej 65. roku życia o największym zużyciu leków generuje 50\% całkowitych kosztów farmakoterapii (Anderson, Kerluke, 1996). 
Zasadniczo leki służą zdrowiu i podnoszą jakość życia dzięki znoszeniu bólu i dolegliwości, oddalając konieczność stosowania inwazyjnych metod leczenia. Przyjmowanie ich obarczone jest jednak ryzykiem. Nieodpowiednio dobrane czy łączone, mogą same stanowić poważne zagrożenie dla pacjenta. Bezpieczeństwo osoby starszej może być jeszcze bardziej zagrożone, kiedy pojawiają się dodatkowe, często uwarunkowane wiekiem błędy przy stosowaniu leków. Najczęstszymi są stosowanie ich bez zalecenia, nieregularnie lub w nieodpowiedniej dawce. Poważny problem może stanowić również właściwy skład przepisanych leków, kupowanych przez chorych z nieznanych źródeł. Pomyłki przy stosowaniu leków mogą być także skutkiem nieczytelnego pisma wystawiającego zlecenie, błędnie obliczonej dawki, niewłaściwej komunikacji między lekarzem a pacjentem, źle zrozumianych ulotek i informacji medycznych. Kłopoty pojawiające się u pacjenta mogą również wynikać z interakcji bądź łączenia kilku leków - w tym dostępnych bez recepty. Osoby starsze najczęściej są leczone równolegle przez wielu lekarzy specjalistów, co nierzadko skutkuje zjawiskiem polipragmazji - czyli równoczesnego zażywania wielu leków bez znajomości mechanizmów ich działania oraz występujących między nimi interakcji lub zażywania przynajmniej jednego leku, dla którego nie ma wskazań. Mimo że wielu pacjentów może uzyskiwać korzyści z takiego leczenia, w populacji geriatrycznej zdecydowanie wiąże się ono z ryzykiem działań niepożądanych. Ocenia się, że 1 na 5 leków stosowanych przez seniorów może być używany niewłaściwie; wśród pensjonariuszy domów opieki stosunek ten wzrasta do nawet 1 na 3 leki (Haighton i wsp. 2016). Nieuzasadniona politerapia nasila niepełnosprawność, może prowadzić do pogorszenia stanu zdrowia, a nawet śmierci. Rozwiązaniem byłby większy dostęp do opieki geriatrycznej i rehabilitacji, czego system opieki zdrowotnej w swoim obecnym kształcie nie jest w stanie zapewnić chorym w zaawansowanym wieku (Pieprzyk, Pieprzyk, 2012). W takiej sytuacji prowadzenie edukacji zdrowotnej wśród osób starszych z naciskiem na zagadnienia związane z przyjmowaniem leków, wydaje się kluczowa. Głównym jej aspektem będzie zapoznanie się z zasadami bezpiecznego ich stosowania.

\section{Najważniejsze zasady prawidłowego stosowania leków}

Przed wypisaniem leku przez lekarza, należy podać informacje dotyczące swoich alergii. Dobrze jest przygotować i pokazywać (na pierwszej wizycie i zawsze, gdy nastąpią zmiany) pełną listę przyjmowanych leków, zarówno 
na receptę, jak i zakupionych bez przepisu lekarza. Należy zasięgać informacji o wskazaniach do bezpiecznego stosowania, ilości i częstotliwości zażywania, środkach bezpieczeństwa, możliwych działaniach ubocznych i postępowaniu w razie ich wystąpienia. Warto również prosić lekarza o dokładne rozpisanie schematu stosowania leku, a w razie wątpliwości, pytać farmaceutę o wyjaśnienie. Nawet otrzymując lek o działaniu podobnym do wcześniej przyjmowanego, należy upewnić się, że posiadamy o nim wszelkie informacje.

W przyjmowaniu leków niezwykle istotna jest regularność: dobrym pomysłem jest ustawienie alarmu przypominającego o konieczności zażycia leku lub naklejanie karteczek (np. na lodówce) i po przyjęciu leku ich zrywanie. Przy lekach w postaci płynnej, warto prosić farmaceutę o zaprezentowanie sposobu odmierzania dawki. Warto również zgłaszać lekarzowi problemy z przełykaniem, ponieważ nie każdy lek można rozdrobnić lub rozpuścić. W aptekach dostępne są specjalne urządzenia do dzielenia tabletek, przy czym pamiętać należy, że nie wszystkie tabletki można dzielić. Istnieją także postaci leków, które rozpuszczają się w jamie ustnej, eliminując problem związany z przełykaniem. Większość leków należy popijać wodą, chyba że lekarz lub producent zaleca inaczej. W przypadku niektórych leków ważne jest ponadto to, co jemy podczas przyjmowania; dotyczy to chociażby tych stosowanych w osteoporozie czy niektórych antybiotyków, których nie wolno łączyć z produktami mlecznymi. W przypadku zażywania kilku leków jednoczasowo, ważne jest, czy nie ma pomiędzy nimi interakcji. Leki należy przyjmować w spokoju, aby wyeliminować ryzyko pomyłki i nigdy w pozycji leżącej, ze względu na ryzyko zachłyśnięcia. W leczeniu osoby starszej nie do przecenienia jest udział opiekuna, który powinien prowadzić nadzór i kontrolę nad prawidłowym przyjmowaniem leku, a w razie potrzeby zgłaszać wszelkie problemy, co może pomóc lekarzowi w natychmiastowej reakcji i modyfikacji dotychczasowej lub doborze innej terapii.

Istotne jest odpowiednie przechowywanie leków, które zawsze należy trzymać w oryginalnym opakowaniu, chronić przed wilgocią, zbyt wysoką temperaturą, światłem oraz dostępem dzieci. Niektóre substancje muszą być przechowywane w lodówce. Okresowo warto sprawdzać czy posiadane w domu leki są nadal ważne i nigdy nie stosować ich po upływie daty ważności. Leki przeterminowane należy wyrzucać do specjalnych pojemników przeznaczonych do ich utylizacji, znajdujących się w większości aptek. Zdarza się, że na opakowaniu podane są również informacje dotyczące okresu, przez jaki dozwolone jest stosowanie leku po otwarciu opakowania (np. syropów czy kropli do oczu). Przydatne jest wówczas zapisywanie na opako- 
waniu daty otwarcia preparatu. Nie należy wyrzucać ulotki, a w przypadku zgubienia, można poprosić farmaceutę o jej kopię.

\section{Używanie i nadużywanie substancji psychoaktywnych przez osoby starsze}

Odrębnym problemem, związanym z nieprawidłowym lub długotrwałym przyjmowaniem leków, może być ich nadużywanie i/lub uzależnienie. Pacjenci powyżej 65. roku życia zażywają około jednej trzeciej wszystkich leków na receptę, często zawierających benzodiazepiny lub opiatowe środki przeciwbólowe. Prawdopodobieństwo otrzymywania recepty na leki psychoaktywne i niewłaściwego ich przyjmowania jest większe w grupie starszych kobiet niż mężczyzn (Gossop, 2008). Problemowe używanie substancji przez osoby starsze może być również spowodowane sposobem leczenia, w którym podczas stosowania różnych leków, wchodzących ze sobą w liczne reakcje, nie prowadzi się regularnego monitorowania czynników mogących powodować uzależnienie. Ważne są także okoliczności i powody nadużywania leków, które mogą być zamierzone bądź nie. Problem może bowiem rozpocząć się od pojedynczych przypadków niewłaściwego zażycia lub nieodpowiedniego stosowania leków (np. pożyczenie leku od innej osoby), a następnie przejść w stan okresowego używania, aż do stałego nadużywania. Towarzyszyć może temu wystąpienie tolerancji i uzależnienie fizyczne. Świadome niewłaściwe zażywanie leków - będące zdecydowanie rzadszym zjawiskiem - charakteryzuje się natomiast zamierzonym zażywaniem dawek wyższych niż zalecane przez dłuższy okres, gromadzeniem leków oraz przyjmowaniem ich $\mathrm{w}$ połączeniu $\mathrm{z}$ alkoholem, co niesłusznie przypisywane jest zazwyczaj wyłącznie młodszym grupom wiekowym (Gossop, 2008).

Wiek podeszły zwiększa ryzyko wystąpienia problemów zdrowotnych, psychologicznych i społecznych (Korzeniowska i wsp. 2015). Wśród ryzykownych czynników rozwoju uzależnienia wymienia się wiele zjawisk związanych ze starzeniem: zły stan zdrowia, przewlekły ból, niepełnosprawność, pozamedyczne używanie substancji, współwystępowanie zaburzenia psychicznego, bezsenność, żałobę, stres, zmniejszenie aktywności towarzyskiej, utratę osób ważnych czy samotność (Storr, Green, 2014). Wystąpienie wraz z procesem starzenia się dolegliwości, poważnych i nieuleczalnych chorób czy trudnych sytuacji w powyższych obszarach może skłaniać osoby starsze do nadużywania leków. Niestety, częściowo z powodu niespecyficznego obrazu klinicznego, utrudnionej aplikacji kryteriów diagno- 
stycznych pomijających specyfikę uzależnienia u seniorów czy ułatwionego dostępu do substancji, uzależnienie od leków u osób starszych jest mniej widoczne niż w młodszych grupach wiekowych i jest wciąż zbyt rzadko diagnozowane. Zachowania, które mogłyby świadczyć o tym, że osoba starsza ma problem z uzależnieniem, nierzadko są traktowane jako swoiste dla wieku. Najbardziej widoczne objawy, takie jak zaburzenia poznawcze, niedożywienie, częstsze upadki, lekarze wciąż jeszcze skłonni są przypisywać głównie demencji i zniedołężnieniu. Nie oznacza to jednak, że zaawansowany wiek uniemożliwia leczenie uzależnień substancjalnych; terapia, mimo braku jednoznacznych wytycznych do jej prowadzenia, może charakteryzować się skutecznością podobną jak w młodszych grupach wiekowych (Kwiatkowski i wsp., 2017).

\section{Refleksje końcowe}

Proces starzenia się jako okres głębokich przemian, dotyczących zarówno sfery fizycznej, jak i psychicznej, stanowi niemałe wyzwanie. Nie wszystkim seniorom udaje się przystosować do nowych warunków. W Polsce brak dobrze przemyślanej polityki wobec ochrony zdrowia osób starszych, co być może wynika z zakorzenionego w społeczeństwie sposobu myślenia o opiece nad nimi jako obowiązku ciążącym głównie na rodzinie. W tej sytuacji bardzo ważnym aspektem staje się przekazanie prozdrowotnych zasad codziennego życia w wieku starszym. Nieoceniona jest tutaj rola, jaką powinna spełniać edukacja zdrowotna, kierowana bezpośrednio do osób starszych, jak i społeczeństwa, tak, aby uświadamiać zarówno problemy związane ze starością, jak i pozytywne jej aspekty.

\section{Bibliografia}

Anderson G., Kerluke J. (1996), Distribution of prescription drug exposures in the elderly: description and implications, „J Clin Epidemiol”, 49, s. 929-935.

Główny Urząd Statystyczny (2014), Prognoza ludności na lata 2014-2015, Zakład Wydawnictw Statystycznych, Warszawa.

Główny Urząd Statystyczny (2011), Rocznik demograficzny 2011, Zakład Wydawnictw Statystycznych, Warszawa.

Gossop M. (2008), Zażywanie substancji przez osoby starsze: zaniedbywany problem, „Cel - Narkotyki”, nr 18, Urząd Oficjalnych Publikacji Wspólnot Europejskich, Europejskie Centrum Monitorowania Narkotyków i Narkomanii. 
Haighton C., Wilson G., Ling J. i wsp. (2016), A qualitative study of service provision for alcohol - related health issues in mid to later life, „PLoS One”, 11 (2): e014601.

Halicki J. (2010), Obrazy starości rysowane przeżyciami seniorów, Wydawnictwo Uniwersytetu w Białymstoku, Białystok.

Korzeniowska K., Cieślewicz A., Zasadzka E., Borowicz A., Pawlaczyk M., Jabłecka A. (2015), Analiza problemu uzależnień w grupie osób w wieku podeszłym, „Przegląd Lekarski”, 72(3), s. 111-114.

Ksiądzyna D., Szeląg A. (2013), Specyfika farmakoterapii pacjentów w podeszłym wieku, „Psychogeriatria Polska”, 10(3), s. 115-126.

Kwiatkowski M., Wygnał N., Simonienko K. i wsp. (2017), Uzależnienie od leków w populacji osób starszych, [w:] Cybulski M., Krajewska-Kułak E., Kędziora-Kornatowska K., Waszkiewicz N. (red.), Psychogeriatria, PZWL, Warszawa.

Lochner K.A., Cox Ch.S. (2013), Prevalence of Multiple Chronic Conditions Among Medicare Beneficiaries, United States, „Prev Chronic Dis”, 10, s. 120-137.

Pieprzyk M., Pieprzyk P. (2012), Osoby starsze w systemie ochrony zdrowia, „Ruch Prawniczy, Ekonomiczny i Socjologiczny”, 3, s. 175-188.

Wolański N. (2005), Rozwój biologiczny człowieka, Wydawnictwo Naukowe PWN, Warszawa.

Storr C.L., Green K. M. (2014), Progression form Substance Use to the Development of Substance Use Disorders, [w:] Crome I., Wu L.T., Rao R.T i wsp. (red.), Substance Use and Older People, Wiley - Blackwell, Hoboken.

Szymborski J., Iwińska K., Przewoźniak K., Błaszczyk K., Troszyński M., Szylar A. (2014), Interdyscyplinarna szkoła promocji zdrowia seniorów, Collegium Civitas, Warszawa, s. 39.

Wolff J.L., Starfield B., Anderson G. (2002), Prevalence, expenditures, and complications of multiple chronic conditions in the elderly, „Arch. Int. Med”, 162, s. 2269-2276.

World Population Ageing Highlights (2015), Department of Economic and Social Affairs, United Nations, New York. 